\title{
PENGARUH ELECTRONIC WORD OF MOUTH TERHADAP MINAT BELI RESERVASI HOTEL
}

\author{
Rusyaima Farha Salsabila ${ }^{1}$ \\ Fakultas Ekonomi dan Bisnis, \\ Universitas Sahid \\ Ekayana Sangkasari Paranita ${ }^{2}$ \\ Fakultas Ekonomi dan Bisnis, \\ Universitas Sahid
}

\begin{abstract}
Abstrak
Penelitian ini dilatarbelakangi oleh semakin meningkatnya pengguna internet yang dimanfaatkan sebagai media promosi oleh online travel agent. Penelitian ini akan menganalisis pengaruh electronic word of mouth terhadap minat beli reservasi hotel via aplikasi Traveloka, baik dari sudut intensity, valence of opinion, maupun content. Dalam penelitian ini peneliti menggunakan metode kuantitatif. Pengumpulan data penelitian ini dengan cara menyebar kuesioner melalui google form yang didistribusikan kepada masyarakat yang sudah pernah melakukan reservasi hotel melalui aplikasi Traveloka. Metode analisis data yang digunakan adalah Regresi Linear Berganda. Hasil penelitian menunjukkan bahwa secara parsial variabel intensity dan content berpengaruh positif signifikan terhadap minat beli reservasi hotel, namun secara simultan ketiga variabel berpengaruh positif signifikan terhadap minat beli reservasi hotel.
\end{abstract}

Kata kunci: intensity, valence of opinion, content, minat beli

*) Corresponding Author: ekayana_sparanita@usahid.ac.id

\section{PENDAHULUAN}

Di era global saat ini, internet sudah menjadi bagian dari kehidupan kita sehari-hari. Pada tahun 2019 hingga kuartal kedua tahun 2020, dari populasi 266,9 juta jiwa penduduk Indonesia, terdapat 196,7 juta jiwa atau 73,06 persen penduduk yang sudah terhubung ke internet (APJII, 2020). Dengan demikian pasar e-commerce menjadi tambang emas yang sangat menggoda bagi sebagian kalangan yang dapat melihat potensinya. Tren e-commerce makin populer berkat kehadiran internet dan smartphone.

Kemajuan teknologi dan informatika yang semakin berkembang sangat memudahkan manusia dalam melakukan aktifitas sehari-hari. Kita dapat memenuhi kebutuhan kita dengan mudah dan cepat, bahkan pembelian apapun dapat dilakukan dengan aplikasi e-commerce yang berada di telepon genggam kita.

Internet memungkinkan semua orang dapat mencari informasi hal-hal yang akan kita lakukan, membuat relasi dengan orang-orang baru, bahkan dapat melakukan transaksi jual-beli secara virtual. Kemajuan teknologi yang canggih membuat penggunanya dapat lebih mudah mengakses segala situs dan aplikasi. Fenomena ini dimanfaatkan pemasar atau pelaku pasar dalam mempromosikan produk dan jasa mereka di media sosial.

Media sosial berperan kuat mempengaruhi konsumen dalam pembelian barang. Konsumen biasanya mencari informasi produk atau jasa yang akan dibelinya dengan melihat ulasan di media sosial. Ulasan produk yang dibuat oleh pengguna online sangatlah berdampak besar terhadap keputusan pembelian seseorang. Hal ini membuat konsumen $e$-business lebih kritis dalam memilih produk yang ditawarkan.

Semakin meningkatnya pengguna internet dimanfaatkan juga oleh online travel agent. Perkembangan Online Travel Agent (OTA) di Indonesia terutama di sektor jasa perhotelan, memberikan keuntungan kepada pelanggan karena menyediakan banyak pilihan dalam melakukan reservasi secara online. Perusahaan online travel agent seperti Traveloka, Pegipegi, Tiket.com, Red Doorz, dan lainlain menyediakan kolom khusus ulasan dari orang-orang yang sudah pernah melakukan booking online dan sudah menginap di hotel tersebut. Konsumen dapat menyimak dan merespon ulasan konsumen lain untuk mengetahui pengalaman konsumen tersebut dalam melakukan pembelian serta dalam menikmati pelayanan hotel. Proses komunikasi antarkonsumen melalu internet dinamakan electronic word of mouth. Dewasa ini electronic word of mouth menjadi media komunikasi untuk saling berbagi informasi 
mengenai suatu produk atau jasa yang telah dikonsumsi antarkonsumen yang tidak saling mengenal dan bertemu sebelumnya.

Dalam industri pariwisata, konsumen yang akan berlibur pasti terlebih dahulu mencari informasi hotel melalui internet. Para konsumen akan meminta rekomendasi melalui ulasan konsumen yang pernah menikmati hotel tersebut. Konsumen akan memutuskan membeli reservasi suatu hotel melalui ulasan yang positif atau menghindari suatu hotel berdasarkan ulasan negatif, kemudian membandingkan produk lain yang disarankan oleh konsumen lainnya.

Electronic word of mouth atau yang biasa kita kenal sebagai komunikasi dari mulut ke mulut terhadap suatu produk atau jasa sudah tidak asing lagi dalam dunia pemasaran. Ketika seorang konsumen merasa puas terhadap produk atau jasa yang dibeli, mereka cenderung akan memberitahukan pengalamannya kepada orang lain. Ini merupakan sebuah metode promosi yang efektif dan efisien karena dapat menjadi media iklan perusahaan tanpa biaya yang banyak karena promosi berasal datang langsung dari pengalaman pelanggan. Terdapat tiga dimensi dalam electronic word of mouth yaitu, Intensity, Valence of Opinion dan Content.

Seiring berjalannya waktu, banyak bermunculan aplikasi online booking seperti Traveloka, RedDoorz, PegiPegi, Tiket.com, dan sebagainya. Maraknya aplikasi online mendorong semakin ketatnya persaingan antar online travel agent. Berikut adalah data pengguna aplikasi online travel agent menurut Google Playstore:

Tabel 1. Pengguna Aplikasi OTA Tahun 2019

\begin{tabular}{ccc}
\hline No. & Aplikasi & Jumlah Pengguna \\
\hline 1. & Traveloka & 10 Juta+ \\
2. & RedDoorz & 5 Juta+ \\
3. & PegiPegi & 5 Juta+ \\
4. & Tiket.com & 5 Juta+ \\
\hline \multicolumn{2}{l}{ Sumber: Google Playstore (2020) }
\end{tabular}

Berdasarkan Tabel 1 di atas dapat diketahui bahwa aplikasi yang paling banyak digunakan di Indonesia adalah Traveloka sebanyak 10 juta lebih pengguna. Oleh karena itu, penelitian ini akan menganalisis electronic word of mouth pada pengguna aplikasi Traveloka.

Perusahaan yang didirikan pada tahun 2012 ini semula memiliki konsep sebagai search engine untuk membandingkan harga tiket pesawat dari sejumlah situs. Seiring perkembangannya, pada tahun 2013 Traveloka menjadi situs pemesanan tiket pesawat. Tahun 2014, Traveloka mulai memasuki bisnis reservasi hotel. Aplikasi Traveloka sudah mencapai lebih dari 40 juta kali diunduh oleh pengguna telepon seluler, hal ini membuat Traveloka menjadi aplikasi telepon seluler paling popular dan diminati para pengguna di Asia Tenggara (APJII, 2020).

Berdasarkan latar belakang yang telah dijelaskan di atas, penelitian ini akan menganalisis pengaruh electronic word of mouth terhadap minat beli reservasi hotel via aplikasi Traveloka, baik dari sudut intensity, valence of opinion, maupun content.

\section{METODE}

Metode penelitian ini menggunakan pendekatan kuantitatif, yaitu penelitian dengan data kuantitatif yang kemudian diolah dan dianalisis untuk diambil kesimpulannya. Populasi penelitian ini adalah masyarakat Indonesia berusia 17 tahun ke atas yang sudah pernah melakukan reservasi hotel online melalui aplikasi Traveloka. Teknik pengambilan sampel adalah probability sampling yaitu teknik pengambilan sampel yang memberikan peluang/kesempatan yang sama bagi setiap unsur atau anggota populasi untuk dipilih menjadi anggota sampel. Ukuran sampel diperoleh dengan berdasarkan teknik Slovin.

Operasionalisasi variabel diperlukan guna menentukan jenis dan indikator variabel terkait dalam penelitian ini, sebagai berikut: 
Tabel 2. Operasionalisasi Variabel

\begin{tabular}{|c|c|}
\hline Variabel & Indikator \\
\hline Intensity (X1) & 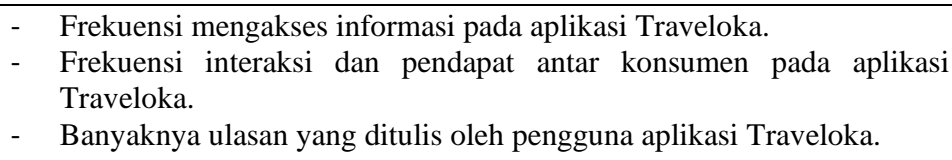 \\
\hline Valence of opinion (X2) & $\begin{array}{ll}\text { - } & \text { Komentar positif dari pengguna aplikasi Traveloka. } \\
\text { - } & \text { Rekomendasi konsumen dari aplikasi Traveloka. } \\
\text { - } & \text { Komentar negatif dari pengguna aplikasi Traveloka. }\end{array}$ \\
\hline Content (X3) & $\begin{array}{l}\text { - Informasi kualitas hotel dalam aplikasi Traveloka. } \\
\text { - Informasi harga yang ditawarkan pada aplikasi Traveloka. } \\
\text { - Informasi kenyamanan, kebersihan, pelayanan hotel pada aplikasi } \\
\text { Traveloka. }\end{array}$ \\
\hline Minat beli reservasi hotel (Y) & $\begin{array}{l}\text { Keputusan transaksional : } \\
\text { Konsumen tertarik untuk menginap setelah mengunjungi Traveloka. } \\
\text { - } \text { Keputusan referensial : } \\
\text { Konsumen berminat untuk mereferensikan hotel tersebut kepada orang } \\
\text { - lain. } \\
\text { Keputusan preferensial : } \\
\text { Konsumen lebih memilih untuk menginap di hotel yang disarankan } \\
\text { pengguna aplikasi Traveloka. } \\
\text { Keputusan eksploratif : } \\
\text { Konsumen berminat mencari informasi lebih dalam di aplikasi } \\
\text { Traveloka. }\end{array}$ \\
\hline
\end{tabular}

Teknik pengumpulan data yang digunakan dalam penelitian ini adalah kuesioner. Kuesioner didistribusikan kepada responden yang memenuhi kriteria sampel. Penggunaan kuesioner via Google Form digunakan karena jumlah responden yang cukup tersebar sehingga lebih efisien. Pilihan jawaban dalam kuesioner terdiri dari lima opsi, berdasarkan skala Likert. Menurut Ghozali (2016), skala likert merupakan metode pengukuran yang digunakan untuk mengulur sikap, pendapat dan persepsi seseorang atau sekelompok orang tentang fenomena sosial. Dalam pertanyaan kuesioner ini digunakan lima kategori jawaban yaitu (SS) sangat sering, (S) sering, (CS) cukup sering, (TS) tidak sering, dan (STS) sangat tidak sering. Berikut nilai yang digunakan dalam kuesioner penelitian ini:

(SS) Sangat Sering $\quad: 5$

(S) Sering : :4

(CS) Cukup Sering $\quad: 3$

(TS) Tidak Sering : 2

(STS) Sangat Tidak Sering $\quad: 1$

Teknik analisis yang digunakan dalam penelitian ini adalah regresi linier berganda. Analisis regresi linear berganda digunakan untuk menganalisis arah hubungan antara variabel independen (Intensity, Valence of Opinion, Content) terhadap variabel dependen (Minat Beli Reservasi Hotel). Persamaan regresi dapat dituliskan sebagai berikut:

Keterangan :

$$
\mathrm{Y}=\beta_{0}+\mathrm{b}_{1} \mathrm{X}_{1}+\mathrm{b}_{2} \mathrm{X}_{2}+\mathrm{b}_{3} \mathrm{X}_{3}+\mathrm{e}
$$

$\mathrm{Y} \quad=$ Minat Beli Reservasi Hotel

ßo $=$ Konstanta

$\mathrm{b}_{1,2,3}=$ Koefisien Regresi

$\mathrm{X}_{1}=$ Intensity

$\mathrm{X}_{2}=$ Valence of Opinion

$\mathrm{X}_{3}=$ Content

$\mathrm{e}=$ Error 
Menurut Ghozali (2016) koefisien determinasi $\mathrm{R}^{2}$ pada intinya mengukur seberapa jauh model dalam menerangkan variabel dependen. Nilai koefisien determinasi adalah nol dan satu. Nilai $\mathrm{R}^{2}$ mendekati nol berarti kemampuan variabel-variabel independen dalam menjelaskan variasi variabel dependen sangat terbatas. Nilai yang mendekati satu berarti variabel-variabel independen memberikan hampir semua informasi yang dibutuhkan untuk memprediksi variasi variabel independen.

\section{HASIL DAN PEMBAHASAN}

Tabel 3 berikut menunjukkan hasil analisis deskriptif rata-rata skor masing-masing indikator variabel electronic word of mouth. Berdasarkan tabel 3 dapat disimpulkan bahwa dari ketiga indikator dalam variabel electronic word of mouth yaitu Intensity, Valence of Opinion dan Content yang memiliki rata-rata skor tertinggi adalah indikator Intensity yaitu frekuensi pengguna dalam menggunakan aplikasi Traveloka.

Tabel 3. Rata-Rata Skor Variabel Electronic Word of Mouth

\begin{tabular}{|c|c|c|c|c|c|c|c|c|c|}
\hline \multirow{3}{*}{ No. } & \multirow{3}{*}{ Pernyataan } & \multicolumn{5}{|c|}{ Pilihan Jawaban } & \multirow{3}{*}{$\begin{array}{l}\text { Total } \\
\text { Nilai }\end{array}$} & \multirow{3}{*}{$\begin{array}{l}\text { Nilai } \\
\text { Rata- } \\
\text { Rata }\end{array}$} & \multirow{3}{*}{$\begin{array}{c}\text { Keteran } \\
\text { gan }\end{array}$} \\
\hline & & SS & $\mathbf{S}$ & CS & TS & STS & & & \\
\hline & & 5 & 4 & 3 & 2 & 1 & & & \\
\hline \multicolumn{10}{|c|}{ Intensity } \\
\hline 1. & $\begin{array}{l}\text { Saya lebih sering menggunakan aplikasi } \\
\text { Traveloka daripada online travel agent } \\
\text { lainnya. }\end{array}$ & 43 & 38 & 16 & 3 & & 421 & 4,21 & $\begin{array}{l}\text { Sangat } \\
\text { Sering }\end{array}$ \\
\hline 2. & $\begin{array}{l}\text { Saya sering melihat/membaca ulasan } \\
\text { yang ditulis oleh pengguna aplikasi } \\
\text { Traveloka. }\end{array}$ & 42 & 40 & 16 & 2 & & 422 & 4,22 & $\begin{array}{l}\text { Sangat } \\
\text { Sering }\end{array}$ \\
\hline 3. & $\begin{array}{l}\text { Aplikasi Traveloka memberikan banyak } \\
\text { ulasan terkait hotel yang dicari. }\end{array}$ & 35 & 53 & 10 & 1 & & 419 & 4,19 & Sering \\
\hline \multicolumn{10}{|c|}{ Valence of Opinion } \\
\hline 4. & $\begin{array}{l}\text { Saya cenderung membaca ulasan yang } \\
\text { positif terhadap hotel yang akan saya } \\
\text { pesan di Traveloka. }\end{array}$ & 37 & 34 & 22 & 7 & & 401 & 4,01 & Sering \\
\hline 5. & $\begin{array}{l}\text { Saya memesan hotel berdasarkan } \\
\text { rekomendasi tamu yang sudah pernah } \\
\text { menginap di hotel yang akan saya pesan. }\end{array}$ & 34 & 43 & 19 & 4 & & 407 & 4,07 & Sering \\
\hline 6. & $\begin{array}{l}\text { Saya tidak akan merespon ulasan yang } \\
\text { negatif terhadap hotel yang akan saya } \\
\text { pesan di Traveloka. }\end{array}$ & 22 & 33 & 28 & 11 & 6 & 354 & 3,54 & Sering \\
\hline \multicolumn{10}{|c|}{ Content } \\
\hline 7. & $\begin{array}{l}\text { Traveloka memberikan informasi } \\
\text { tentang kualitas hotel dalam bentuk } \\
\text { rating. }\end{array}$ & 41 & 45 & 12 & 2 & & 425 & 4,25 & $\begin{array}{l}\text { Sangat } \\
\text { Sering }\end{array}$ \\
\hline 8. & $\begin{array}{l}\text { Traveloka memberikan jaminan harga } \\
\text { yang terbaik. }\end{array}$ & 24 & 46 & 24 & 5 & 1 & 387 & 3,87 & Sering \\
\hline 9. & $\begin{array}{l}\text { Traveloka memberikan informasi } \\
\text { tentang kenyamanan, keamanan dan } \\
\text { kebersihan hotel secara rinci. }\end{array}$ & 33 & 39 & 25 & 3 & & 402 & 4,02 & Sering \\
\hline \multicolumn{8}{|c|}{ Rata-Rata } & 4,04 & Sering \\
\hline
\end{tabular}

Sumber: Diolah (2020)

Tabel 4 berikut menunjukkan hasil analisis deskriptif rata-rata skor masing-masing indikator variabel minat beli reservasi hotel. Berdasarkan tabel 4 dapat disimpulkan bahwa dari keempat indikator dalam variabel minat beli reservasi hotel yang memiliki rata-rata skor tertinggi adalah keputusan preferensial yaitu keputusan untuk memilih hotel yang disarankan oleh pengguna Traveloka dengan ulasan yang positif. 
Tabel 4. Rata-Rata Skor Variabel Minat Beli Reservasi Hotel

\begin{tabular}{|c|c|c|c|c|c|c|c|c|c|}
\hline \multirow{3}{*}{ No. } & \multirow{3}{*}{ Pernyataan } & \multicolumn{5}{|c|}{ Pilihan Jawaban } & \multirow{3}{*}{$\begin{array}{l}\text { Total } \\
\text { Nilai }\end{array}$} & \multirow{3}{*}{$\begin{array}{l}\text { Nilai } \\
\text { Rata- } \\
\text { Rata }\end{array}$} & \multirow{3}{*}{$\begin{array}{c}\text { Keteran } \\
\text { gan }\end{array}$} \\
\hline & & SS & $\mathbf{S}$ & CS & TS & STS & & & \\
\hline & & 5 & 4 & 3 & 2 & 1 & & & \\
\hline \multicolumn{10}{|c|}{ Keputusan Transaksional } \\
\hline 1. & $\begin{array}{l}\text { Saya tertarik untuk melakukan transaksi } \\
\text { setelah mengunjungi dan membaca } \\
\text { ulasan di aplikasi Traveloka }\end{array}$ & 23 & 51 & 24 & 2 & & 395 & 3,95 & Setuju \\
\hline \multicolumn{10}{|c|}{ Keputusan Referensial } \\
\hline 2. & $\begin{array}{l}\text { Saya merekomendasikan orang lain } \\
\text { akan hotel yang saya sudah pilih melalui } \\
\text { aplikasi Traveloka }\end{array}$ & 29 & 50 & 16 & 3 & 2 & 401 & 4,01 & Setuju \\
\hline \multicolumn{10}{|c|}{ Keputusan Preferensial } \\
\hline 3. & $\begin{array}{l}\text { Saya lebih memilih untuk menginap di } \\
\text { hotel yang disarankan oleh pengguna } \\
\text { aplikasi Traveloka dengan ulasan yang } \\
\text { positif }\end{array}$ & 39 & 44 & 25 & 2 & & 450 & 4.50 & $\begin{array}{l}\text { Sangat } \\
\text { setuju }\end{array}$ \\
\hline \multicolumn{10}{|c|}{ Keputusan Eksploratif } \\
\hline 4. & $\begin{array}{l}\text { Saya akan mencari informasi lebih } \\
\text { terkait dengan hotel yang akan saya } \\
\text { pesan di aplikasi Traveloka }\end{array}$ & 48 & 41 & 9 & 2 & & 394 & 3.94 & Setuju \\
\hline \multicolumn{8}{|c|}{ Rata-Rata } & 4,01 & Setuju \\
\hline
\end{tabular}

Sumber: Diolah (2020)

Dependent Variable: Minat Beli $(Y)$

Tabel 5. Regresi Linear Berganda Coefficients $^{\text {a }}$

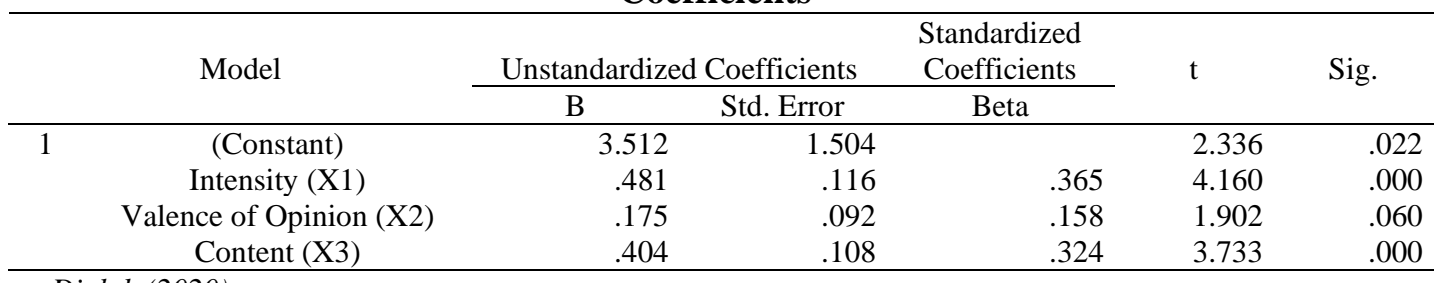

Sumber: Diolah (2020)

Berdasarkan tabel 5 maka dapat diinterpretasikan bahwa:

1. Koefisien $X_{1}$ sebesar 0,481 dengan nilai signifikansi $0,000<0,05$ bermakna bahwa variabel intensity berpengaruh positif signifikan terhadap minat beli reservasi hotel. Hal ini berarti hipotesis 1 diterima. Semakin tinggi frekuensi mengakses informasi, interaksi pendapat antarkonsumen, dan banyaknya ulasan pada aplikasi Traveloka, maka semakin tinggi pula minat pengguna Traveloka untuk melakukan reservasi hotel.

2. Koefisien $X_{2}$ sebesar 0,175 dengan nilai signifikansi 0,060>0,05 bermakna bahwa variabel valance of opinion tidak berpengaruh signifikan terhadap minat beli reservasi hotel. Hal ini berarti hipotesis 2 tidak diterima. Jadi banyak atau sedikitnya ulasan positif yang diberikan oleh pengguna Traveloka lainnya belum tentu menyebabkan peningkatan minat pengguna Traveloka untuk melakukan reservasi hotel.

3. Koefisien $\mathrm{X}_{3}$ sebesar 0,404 dengan nilai signifiksi 0,000 $<0,05$ bermakna bahwa variabel content berpengaruh positif signifikan terhadap minat beli reservasi hotel. Hal ini berarti hipotesis 3 diterima. Semakin lengkap informasi yang diberikan oleh aplikasi Traveloka tentang kenyamanan, 
keamanan, harga serta kebersihan, maka semakin meningkat minat pengguna Traveloka untuk melakukan reservasi hotel.

Dependent Variable: Minat Beli $(Y)$

\begin{tabular}{|c|c|c|c|c|c|c|}
\hline \multicolumn{7}{|c|}{$\begin{array}{c}\text { Tabel 6. Uji F } \\
\text { ANOVA }^{\mathbf{a}}\end{array}$} \\
\hline & Model & Sum of Squares & df & Mean Square & $\mathrm{F}$ & Sig. \\
\hline 1 & Regression & 231.629 & 3 & 77.210 & 25.440 & $.000^{\mathrm{b}}$ \\
\hline & Residual & 291.361 & 96 & 3.035 & & \\
\hline & Total & 522.990 & 99 & & & \\
\hline
\end{tabular}

Sumber: Diolah (2020)

Berdasarkan tabel 6, diketahui bahwa nilai $\mathrm{F}$ hitung sebesar 25,440 dengan signifikansi 0,000 $>0,05$ maka model penelitian dianggap layak. Hal ini juga berarti hipotesis 4 diterima. Intensity, valence of opinion, dan content secara simultan berpengaruh positif signifikan terhadap minat beli reservasi hotel.

Predictors: (Constant), Content (X3), Valance of Opinion (X2), Intensity (X1)

Tabel 7. Koefisien Determinasi

Model Summary

\begin{tabular}{crrrr}
\hline Model & R & R Square & Adjusted R Square & Std. Error of the Estimate \\
\hline 1 & $.666^{\mathrm{a}}$ & .443 & .425 & 1.742 \\
\hline
\end{tabular}

Sumber: Diolah (2020)

Hasil perhitungan koefisien determinasi memperoleh nilai Adjusted R Square sebesar 0,425 yang berarti bahwa variabel-variabel electronic word of mouth menentukan variasi perubahan minat beli reservasi hotel via Traveloka sebesar 42,5 persen. Adapun 57,5 persen lainnya ditentukan oleh variabel-variabel lainnya di luar model penelitian ini.

\section{PENUTUP}

Berdasarkan hasil dan pembahasan analisis penelitian maka dapat disimpulkan bahwa skor tertinggi pada variabel electronic word of mouth adalah pada indikator intensity yaitu frekuensi pengguna dalam menggunakan aplikasi Traveloka. Adapun pada variabel minat beli reservasi hotel skor tertinggi terdapat pada indikator keputusan preferensial yaitu keputusan untuk memilih hotel yang disarankan oleh pengguna Traveloka dengan ulasan yang positif.

Variabel intensity dan content berpengaruh positif signifikan terhadap minat beli reservasi hotel via aplikasi Traveloka. Jadi faktor-faktor yang menentukan minat beli reservasi hotel via aplikasi Traveloka adalah seringnya frekuensi melihat ulasan positif yang diberikan pengguna lain, dan informasi yang sangat detail sehingga memudahkan pengguna dalam memilih hotel yang diinginkan. Adapun variabel valence of opinion tidak berpengaruh signifikan terhadap minat beli reservasi hotel via aplikasi Traveloka. Akan tetapi berdasarkan mean variabel valence of opinion, responden sering memesan hotel berdasarkan rekomendasi dari pengguna lain yang sudah pernah melakukan reservasi sebelumnya.

Berdasarkan analisis pembahasan dan kesimpulan penelitian, direkomendasikan agar fasilitas dalam aplikasi Traveloka ditingkatkan, khususnya pada menu guest comment agar memperluas akses informasi dan memungkinkan konsumen dapat berinteraksi dengan pengguna sebelumnya. Agenda penelitian selanjutnya hendaknya mempertajam analisis dengan menambahkan variabel-variabel eksternal yang dimungkinkan berpengaruh terhadap minat beli reservasi hotel secara online. 


\section{DAFTAR PUSTAKA}

Angkiriwang, D. I., Susanto, K. C., \& Thio, S. (2018). Pengaruh Ulasan Online Di Tripadvisor Terhadap Minat Menginap Generasi Milenial Di Surabaya. Jurnal Hospitality dan Manajemen Jasa, 6(2), p.452-468.

APJII, 2020. Laporan Survei Internet Asosiasi Penyelenggara Jasa Internet Indonesia 20192020 (Q2).

Cashman, V.S. (2007). Discovering Computer: Menjelajah Dunia Komputer Fundamental. Edisi 3. Jakarta : Salemba Infotek.

Ghozali, I. (2016). Aplikasi Analisis Multivariate Dengan Program IBM SPSS 23. Cetakan VIII. Semarang : Badan Penerbit Universitas Diponegoro.

Goyette, I., et al. (2010). e-WOM Scale Word of Mouth Measurement Scale, for E-Service Content. Canadian Journal of Administrative Science, 27(1).

Jap, O., et al. (2018). Faktor-faktor e-WOM yang Mempengaruhi Minat Beli Hotel Secara Online Pada Masyarakat Surabaya Melalui Online Travel Agent (OTA). Jurnal Hospitality Dan Manajemen Jasa, 6(2), p.286-293.

Jalilvand, M. R. \& Samiei, N. (2012). The Effect of Electronic Word of Mouth on Brand Image and Purchase Intention : An Empirical Study in The Aoutomobile Industry in Iran. Marketing Intelligence \& Planning, 30(4).

Jotopurnomo, S. \& Samuel, S.L.H. (2015). Pengaruh Harga, Brand Image, dan Electronic Word of Mouth Terhadap Minat Beli Reservasi Hotel Secara Online. Jurnal Hospitality dan Manajemen Jasa, 3(1).

Kietzman, H. J. \& Canhoto, A. (2013). Bittersweet! Understanding and Managing Electronic Word of Mouth. Journal of Public Affairs.

Kotler, P., \& Keller, K. L. (2009). Marketing Management (13 ${ }^{\text {rd }}$ ed). United States of America: Pearson Prentice Hall.

Schiffman, L. G., Kanuk, L. L. \& Wisenblit, J. (2010). Consumer Behavior $\left(10^{\text {th }}\right.$ ed). United States of America: Pearson Prentice Hall.

Sindunata, I. \& Alexander, W. B. (2018). Pengaruh e-WOM (Electronic Word of Mouth) terhadap Keputusan Pembelian di Agoda.com. Jurnal Hospitality dan Manajemen Jasa, $6(1)$.

Thurau, T., et al. (2004). Electronic Word of Mouth Via Consumer Opinion Platform: What Motivate Consumer to Articulate Themselves on The Internet. Journal of Interactive Marketing.

Wong, J. (2010). Internet Making for Beginners. Jakarta : Elex Media Komputindo. 